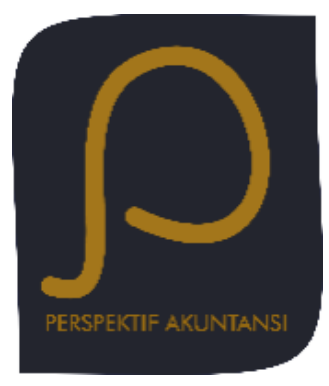

Perspektif Akuntansi

Volume 4 Nomor 1 (Februari 2021), hal. 75-88

ISSN: 2623-0194 (Print), 2623-0186 (Online)

Copyright(C The Authors(s). All Rights Reserved

Center for Accounting Development and Research (CARD)

Fakultas Ekonomika dan Bisnis,

Universitas Kristen Satya Wacana

DOI: https://doi.org/10.24246/persi.vXiX.p75-88

http://ejournal.uksw.edu/persi

\title{
Determinan yang Mempengaruhi Tax Saving pada Klasifikasi Industri Consumer Goods di Indonesia
}

\author{
Meylinda Marditasari ${ }^{1}$ \\ Shinta Permata Sari \\ Universitas Muhammadiyah Surakarta
}

\begin{abstract}
Received
07/04/2021

Revised

28-04-2021

Accepted

$30 / 04 / 2021$

Abstract. Tax is the largest source of national income, but tax payable could burden and reduce corporate profit. Tax saving is company's ability to save tax payable in line with giving attention to the stakeholder point of view about manager's performance in managing the company. This study aims to examine the determinant factors: capital structure, sales growth, depreciation, and the audit committee's financial expertise that affect tax saving. The population of tis study is companies in the consumer goods industry classification that are listed on the Indonesia Stock Exchange in 2017-2019. The sample dertermines using purposive sampling and there are 69 company's data that met the criteria. This study uses secondary data and the hypothesis is tested using multiple linier regression analysis. The results of hypothesis testing show that sales growth and depreciation affect tax saving. Meanwhile, capital structure and audit committee's financial expertise do not affect tax saving
\end{abstract}

Keywords: tax saving, capital structure, sales growth, depreciation, financial expertise

\footnotetext{
${ }^{1}$ meylindaajaoke@gmail.com
} 


\begin{abstract}
Abstrak. Pajak merupakan sumber pendapatan terbesar bagi negara namun pajak terutang dapat membebani dan mengurangi laba perusahaan. Tax saving merupakan upaya perusahaan untuk menghemat pajak terutang namun juga memperhatikan sudut pandang stakeholder atas kinerja manajer dalam mengelola perusahaan. Penelitian ini bertujuan untuk menguji faktor determinan berupa: struktur modal, sales growth, penyusutan, dan keahlian keuangan komite audit yang mempengaruhi tax saving. Populasi penelitian ini adalah perusahaan pada klasifikasi industri consumer goods yang terdaftar di Bursa Efek Indonesia tahun 2017-2019. Penentuan sampel menggunakan purposive sampling dan terdapat 69 data amatan perusahaan yang memenuhi kriteria. Penelitian ini menggunakan data sekunder dan hipotesis diuji dengan analisis regresi linier berganda. Hasil pengujian hipotesis menunjukkan bahwa sales growth dan penyusutan berpengaruh terhadap tax saving. Sedangkan struktur modal dan keahlian keuangan komite audit tidak berpengaruh terhadap tax saving.
\end{abstract}

Kata kunci: tax saving, struktur modal, pertumbuhan penjualan, depresiasi, keahlian keuangan

\title{
Pendahuluan
}

Hampir semua negara di dunia bergantung pada pajak untuk kelangsungan hidup negaranya. Beberapa negara memiliki tingkat pajak yang tinggi, seperti Perancis dengan tarif Pajak Penghasilan (PPh) 75 persen, Aruba dengan tarif PPh 58,95 persen, Swedia dengan tarif 56,6 persen, Denmark dengan tarif 55,4 persen, Belanda dengan tarif 52 persen. Selain itu, Belgia, Austria, Jepang, dan Inggris dengan tarif $\mathrm{PPh}$ 50 persen, serta Finlandia dan Irlandia dengan tarif $\mathrm{PPh}$ 49,2 persen dan 48 persen. Begitu pula dengan aktivitas perekonomian Indonesia, tidak terlepas dari peran pajak didalamnya.

Pajak menjadi tulang punggung keuangan negara. Dalam postur Anggaran Pendapatan dan Belanja Negara (APBN) 2019, penerimaan pajak tercatat menyumbang 82,5 persen dari total pendapatan negara, sesuai penyataan situs resmi Direktorat Jenderal Pajak (2020). Hal ini menunjukkan bahwa untuk menjalankan roda pemerintahan dan akses layanan bagi masyarakat sangat bergantung pada penerimaan dari perpajakan.

Penerimaan negara sebagian besar berasal dari pajak yang disetorkan Wajib Pajak kepada pemerintah berdasarkan tarif yang ditentukan. Semakin tinggi kesadaran wajib pajak untuk membayar pajak, maka semakin banyak pula penerimaan yang didapat oleh pemerintah untuk menjalankan roda perekonomian negara. Perusahaan-perusahaan yang sudah terdaftar dalam Bursa Efek Indonesia memiliki kewajiban untuk membayar pajak karena perusahaan-perusahaan tersebut telah go public, sehingga manajemen harus mempertanggungjawabkan kinerjanya kepada para pemangku kepentingan. Pemerintah juga merupakan salah satu pemangku 
kepentingan karena perusahaan-perusahaan tersebut akan membayar pajak kepada pemerintah atas kegiatan ekonomi yang dilakukannya. Perusahaan perlu melakukan tax saving agar laba perusahaan tetap optimal namun perusahaan tidak melanggar undang-undang perpajakan agar perusahaan-perusahaan tersebut mampu membayar pajak secara konsisten.

Tax saving adalah solusi bagi perusahaan untuk menghemat pajak terutang namun tidak melanggar aturan yang berlaku. Secara logika banyaknya pajak terutang sebanding dengan laba yang dihasilkan perusahaan. Apabila perusahaan memiliki laba yang baik maka pajak terutangnya juga tinggi. Perusahaan akan berupaya untuk meminimalisasi pajak terutang untuk memberikan keuntungan yang lebih besar pada perusahaan namun tidak melanggar peraturan yang menimbulkan sanksi apabila pelanggaran terungkap.

Penelitian mengenai determinan yang mempengaruhi tax saving pada klasifikasi industri consumer goods di Indonesia ini sangatlah menarik. Penelitian-penelitian sebelumnya banyak membahas tentang penghindaran, pelanggaran, dan perencanaan pajak. Akan tetapi, masih sangat sedikit penelitian yang membahas mengenai tax saving. Pada dasarnya tax saving ini justru memberikan pandangan yang lebih baik terhadap perusahaan atas penghematan pajak yang dilakukan. Perusahaan tidak hanya mencari laba maksimal dalam operasinya namun juga mempertimbangkan stakeholder dalam pengambilan keputusan.

Ruchjana (2008) serta Sahilatua dan Noviari (2013), menyatakan bahwa suatu perencanaan pajak yang tepat akan menghasilkan beban pajak yang minimal, yang merupakan hasil dari perbuatan penghematan pajak dan atau penghindaran pajak. Hal tersebut merupakan cara atau tindakan penghematan pajak yang masih dalam koridor perundang-undangan (lawful fashion) (Fani dan Wibowo, 2017). Tax saving merupakan upaya untuk menghemat pengeluaran pajak melalui peraturan suatu peristiwa untuk meminimumkan pajak sesuai dengan ketentuan perpajakan. Tujuan dari penghematan pajak adalah meminimalisasi pengeluaran untuk membayar pajak namun tidak melanggar peraturan perundang-undangan perpajakan sehingga laba bersih perusahaan dapat dioptimalkan namun tetap memenuhi kewajiban membayar pajak yang sesuai dengan aturan atau tidak melakukan penghindaran dan pelanggaran pajak yang berakibat hukum pidana atau perdata di masa yang akan datang.

Menurut Brigham dan Houston (2011) serta penelitian Sudarmika dan Sudirman (2015), teori trade off menjelaskan bahwa struktur modal perusahaan dapat disusun dengan menukar manfaat pajak dari pendanaan utang dengan masalah yang ditimbulkan oleh potensi kebangkrutan. Dengan adanya struktur modal yang tepat, kreditur memberikan pertimbangan untuk memberi pinjaman kepada perusahaan. Dengan pertimbangan ini maka akan menambah utang perusahaan yang dapat mengurangi pajak yang harus dibayar oleh perusahaan. 
Budiman dan Setiyono (2012) serta Aprianto dan Dwimulyani (2019) memberikan gambaran bahwa pertumbuhan penjualan menunjukkan perkembangan tingkat penjualan perusahaan dari tahun ke tahun. Pertumbuhan penjualan yang meningkat akan meningkatkan laba perusahaan yang mengakibatkan pajak yang yang dibayar perusahaan lebih besar. Oleh karena itu, strategi untuk menjaga pertumbuhan penjualan juga diperlukan agar perusahaan dapat melakukan penghematan pajak.

Berdasarkan Undang-Undang (UU) Pajak Penghasilan Nomor 36 (2008), dijelaskan bahwa pengeluaran untuk memperoleh harta berwujud yang mempunyai masa manfaat lebih dari satu tahun harus dibebankan sebagai pengeluaran untuk mendapatkan, menagih, dan memelihara penghasilan dengan mengalokasikan pengeluaran tersebut selama masa manfaat harta tersebut melalui penyusutan (Agoes dan Trisnawati, 2013). Oleh karena itu, pengelolaan depresiasi atas asset perusahaan juga menjadi pertimbangan penting agar penghematan pajak dapat dilakukan, tetapi perusahaan masih mampu menghasilkan laba.

Komite audit juga merupakan bagian dari manajemen perusahaan yang berpengaruh dalam menentukan kebijakan perusahaan yang diharapkan mampu untuk mengurangi beban pajak perusahaan (Puspita dan Harto, 2014). Dengan memperhatikan uraian tentang beberapa determinan tax saving, maka penelitian tentang penghematan pajak perlu dilakukan terutama untuk klasifikasi industri barang konsumen yang memiliki tingkat perputaran modal kerja maupun aset yang cukup tinggi.

\section{Telaah Pustaka}

\section{Tax Saving}

Menurut Undang-Undang Ketentuan Umum dan Tata Cara Perpajakan (KUP) Pasal Satu dijelaskan bahwa pajak adalah kontribusi wajib kepada negara yang terutang oleh orang pribadi atau badan yang bersifat memaksa berdasarkan Undang-Undang, dengan tidak mendapatkan imbalan secara langsung dan digunakan untuk keperluan negara bagi sebesar-besarnya kemakmuran rakyat. Dikarenakan pentingnya peranan pajak ini, maka pemerintah menggencarkan sosialisasi kepada masyarakat untuk membayar pajak. Namun demikian, perusahaan berupaya untuk meminimalkan pembayaran pajak sehingga laba bersih yang diperoleh perusahaan maksimal. Upaya untuk meminimalkan pembayaran pajak ini adalah tax saving. Menurut Djuharni dan Bezaliel (2019), perencanaan pajak dilakukan dengan tujuan agar jumlah yang dibayar perusahaan tidak melebihi dari jumlah yang seharusnya, dan semata-mata bukan untuk menghindari pembayaran pajak. 


\section{Struktur Modal}

Teori trade off menjelaskan struktur modal yang menyatakan bahwa perusahaan menukar manfaat pajak dari pendanaan utang dengan masalah yang ditimbulkan oleh potensi kebangkrutan (Brigham dan Houston, 2011). Struktur modal penting bagi perusahaan karena berpengaruh atas pengambilan keputusan sumber pendanaan perusahaan. Dengan adanya struktur modal, kreditur memberikan pertimbangan untuk memberi pinjaman kepada perusahaan. Dengan pertimbangan ini maka perusahaan menambah utang yang dapat mengurangi pajak yang harus dibayar oleh perusahaan.

\section{Sales Growth}

Pertumbuhan penjualan (sales growth) menunjukkan perkembangan tingkat penjualan dari tahun ke tahun (Budiman dan Setiyono, 2012). Pertumbuhan yang meningkat memungkinkan perusahaan akan lebih meningkatkan kapasitas operasi perusahaan. Sebaliknya bila pertumbuhannya menurun perusahaan akan menemui kendala dalam rangka meningkatkan kapasitas operasinya. Dengan adanya pertumbuhan penjualan maka menunjukkan peningkatan laba yang akan berakibat pada peningkatan jumlah pajak yang akan dibayar (Aprianto dan Dwimulyani, 2019).

\section{Penyusutan}

Pernyataan Standar Akuntansi Keuangan (PSAK) No.16 (IAI 2018), menjelaskan bahwa aset tetap merupakan aset berwujud yang dimiliki untuk digunakan dalam produksi atau penyediaan barang atau jasa untuk tujuan administrasi dan diharapkan digunakan selama lebih dari satu periode. Semua jenis aset tetap memiliki umur manfaat yang terbatas kecuali tanah. Umur manfaat menurut PSAK adalah suatu periode ketika aset diharapkan digunakan oleh entitas dan jumlah produksi atas unit serupa yang diharapkan dari aset tersebut oleh entitas. Berdasarkan UU PPh Nomor 36 Tahun 2008, pengeluaran untuk memperoleh harta berwujud yang mempunyai masa manfaat lebih dari satu tahun harus dibebankan sebagai pengeluaran untuk mendapatkan, menagih, dan memelihara penghasilan dengan mengalokasikan pengeluaran tersebut selama masa manfaat harta tersebut melalui penyusutan (Agoes dan Trisnawati, 2013: 132).

\section{Keahlian Keuangan Komite Audit}

Berdasarkan Peraturan Otoritas Jasa Keuangan Nomor 55/P0JK.04 (2015) menjelaskan pengertian komite audit adalah komite yang dibentuk oleh dan bertanggung jawab kepada Dewan Komisaris dalam membantu melaksanakan tugas dan fungsi Dewan Komisaris. Berdasarkan penelitian sebelumnya yang diamati oleh Puspita dan Harto (2014), komite audit dengan keahlian akuntansi atau keuangan berpengaruh signifikan terhadap keputusan yang diambil perusahaan, sehingga membantu mengontrol manager agar berperilaku sesuai kepentingan pemegang saham. 


\section{Pengembangan Hipotesis}

Struktur modal akan memberikan kreditur pertimbangan atas pinjaman yang diberikan kepada suatu perusahaan. Pinjaman tersebut nantinya menambah utang perusahaan, dan dengan bertambahnya utang maka pajak yang dibayar berkurang. Dalam penelitian Wahyuni dan Suryantini (2014) menunjukkan pengaruh struktur modal terhadap penghematan pajak.

$\boldsymbol{H}_{1}$ : Struktur modal berpengaruh terhadap tax saving.

Penelitian Aprianto dan Dwimulyani (2019) menunjukkan bahwa pertumbuhan penjualan yang meningkat memungkinkan perusahaan lebih meningkatkan kapasitas operasi perusahaan. Sebaliknya, bila pertumbuhannya menurun perusahaan akan menemui kendala dalam rangka meningkatkan kapasitas operasinya. Pertumbuhan penjualan menunjukkan perkembangan dari penjualan perusahaan tahun ke tahun serta menunjukkan peningkatan laba yang berpengaruh terhadap pembayaran pajak (Permata et al., 2018).

$\boldsymbol{H}_{2}$ : Sales growth berpengaruh terhadap tax saving.

Pemilihan metode penyusutan aset tetap berpengaruh terhadap laba serta memengaruhi pajak yang dibayar perusahaan. Dalam penelitian Pernanda dan Arniati (2013) dijelaskan bahwa pemilihan metode penyusutan akan mempengaruhi penghematan pembayaran pajak terutang perusahaan. Penelitian Ritonga (2017) menunjukkan bahwa dilakukannya penyusutan dan revaluasi aset dapat mengoptimalkan beban pajak.

$\boldsymbol{H}_{3}:$ Penyusutan berpengaruh terhadap tax saving.

Penelitian sebelumnya oleh Robinson et al. (2012) menunjukkan keahlian akuntansi atau keuangan komite audit berpengaruh terhadap penghindaran pajak. Namun hasil dari penelitian Puspita dan Harto (2014) menunjukkan keahlian akuntansi atau keuangan komite audit tidak menentukan perilaku penghindaran pajak perusahaan, karena cenderung memilih melakukan penghematan pajak.

$\boldsymbol{H}_{4}$ : Keahlian keuangan komite audit berpengaruh terhadap tax saving. 


\section{Metoda}

\section{Jenis dan Sumber Data}

Penelitian ini merupakan penelitian kuantitatif dengan melakukan uji hipotesis. Data dalam penelitian ini menggunakan data sekunder berupa laporan tahunan (annual report) perusahaan terbuka pada klasifikasi industri consumer goods tahun 20172019 yang didokumentasikan dari situs resmi Bursa Efek Indonesia www.idx.co.id atau web resmi masing-masing perusahaan.

\section{Populasi dan Sampel}

Populasi dalam penelitian ini adalah perusahaan terbuka pada klasifikasi industri consumer goods yang terdaftar di Bursa Efek Indonesia (BEI) selama periode 20172019. Teknik pengambilan sampel menggunakan purposive sampling, dengan kriteria yaitu (1) Perusahaan pada klasifikasi industri consumer goods yang terdaftar di BEI selama periode 2017-2019; (2) Laporan keuangan tahunan tersedia di web resmi BEI atau perusahaan selama periode 2017-2019; (3) Perusahaan yang memiliki laba positif dan mencantumkan beban pajak selama periode penelitian; serta (4) Pertumbuhan penjualan bernilai positif dan sebagian kecil bernilai negatif.

\section{Pengukuran Variabel}

\section{Tax Saving}

Tax saving adalah variabel dependen dalam penelitian ini, merupakan upaya perusahaan untuk menghemat pembayaran pajak namun tetap berdasarkan peraturan perpajakan yang berlaku (Darmadi dan Zulaikha, 2013). Perhitungan tax saving menggunakan Tarif Pajak Efektif (ETR), dengan formula:

\section{Struktur Modal}

$$
\text { Tarif Pajak Efektif }=\frac{\text { Beban Pajak }}{\text { Laba Sebelum Pajak }}
$$

Struktur modal merupakan perimbangan jumlah utang jangka pendek yang bersifat permanen, utang jangka panjang dengan saham preferen dan saham biasa (Sudarmika dan Sudirman, 2015). Pengukuran struktur modal menggunakan Debt Equity Ratio.

$$
\text { Debt to Equity Ratio }=\frac{\text { Total Hutang }}{\text { Total Modal Sendiri }}
$$

Sales Growth

Sales growth dapat diukur dengan penjualan akhir periode pada tahun i dikurangi dengan penjualan akhir periode pada tahun sebelumnya, dibagi dengan penjualan akhir periode tahun sebelumnya (Mahanani et al., 2017).

$$
\text { Sales Growth }=\frac{\text { Penjualan tahun } \mathrm{i}-\text { Penjualan tahun }(\mathrm{i}-1)}{\text { Penjualan tahun }(\mathrm{i}-1)}
$$




\section{Penyusutan}

Dengan memaksimalkan penyusutan dan pemilihan metode penyusutan tertentu dapat memengaruhi besarnya penghematan pajak (Pernanda dan Arniati, 2013). Dalam penelitian ini penyusutan ditentukan dengan besarnya akumulasi penyusutan perusahaan yang tercatat pada annual report dalam satuan milliar rupiah.

\section{Keahlian Keuangan Komite Audit}

Penelitian Puspita dan Harto (2014) keahlian keuangan komite audit diukur dengan persentase anggota komite audit dengan keahlian keuangan terhadap jumlah seluruh komite audit.

$$
\text { Keahlian Keuangan Komite Audit }=\frac{\text { Jumlah Anggota dengan Keahlian Keuangan }}{\text { Jumlah Anggota Komite Audit }}
$$

\section{Metode Analisis Data}

Penelitian ini menggunakan analisis regresi berganda untuk menunjukkan hubungan antara variabel dependen dan independen yang dihipotesiskan. Sebelum melakukan uji regresi linier berganda, dilakukan pengujian asumsi klasik, yaitu uji normalitas dengan uji Kolmogrov-Smirnov; uji multikolinieritas melalui tolerance value (TV) atau nilai variance inflation factor (VIF); uji autokorelasi dengan Durbin-Watson (DW test); dan uji heteroskedastisitas menggunakan uji Glejser (Ghozali, 2011). Adapun model regresi dalam penelitian ini adalah sebagai berikut:

$\mathrm{TS}=\mathrm{a}+\mathrm{b}_{1} \mathrm{SM}+\mathrm{b}_{2} \mathrm{SG}+\mathrm{b}_{3} \mathrm{PYST}+\mathrm{b}_{4} \mathrm{KK}+\mathrm{e}$

Keterangan:

$\begin{array}{lll}\text { TS } & : & \text { Tax Saving } \\ \text { UK } & : & \text { Ukuran Perusahaan } \\ \text { SM } & : & \text { Struktur Modal } \\ \text { SG } & : & \text { Sales Growth } \\ \text { PYST } & : & \text { Penyusutan } \\ \text { KK } & : & \text { Keahlian Keuangan Komite Audit }\end{array}$




\section{Hasil dan Pembahasan}

Dengan memperhatikan kriteria penentuan sampel penelitian, maka penelitian ini menggunakan 23 perusahaan yang termasuk pada klasifikasi industri consumer goods yang terdaftar di BEI selama periode 2017-2019 dengan 69 tahun perusahaan sebagai amatan penelitian. Tabel 1 menjelaskan tentang proses pemilihan sampel penelitian.

\section{Tabel 1. Proses Pemilihan Sampel}

\begin{tabular}{|c|c|c|}
\hline No. & Kriteria & Jumlah \\
\hline 1 & $\begin{array}{l}\text { Perusahaan pada klasifikasi industri consumer goods yang terdaftar } \\
\text { di BEI selama periode } 2017-2019\end{array}$ & 61 \\
\hline 2 & $\begin{array}{l}\text { Laporan keuangan tahunan tidak tersedia di web resmi BEI atau } \\
\text { perusahaan selama periode } 2017-2019\end{array}$ & (19) \\
\hline 3 & $\begin{array}{c}\text { Perusahaan yang tidak memiliki laba positif dan mencantumkan } \\
\text { beban pajak selama periode penelitian }\end{array}$ & $(17)$ \\
\hline 4 & $\begin{array}{c}\text { Pertumbuhan penjualan tidak bernilai positif atau sebagian besar } \\
\text { bernilai negatif. }\end{array}$ & $(2)$ \\
\hline & Jumlah sampel perusahaan yang memenuhi kriteria & 23 \\
\hline & Total sampel yang diolah $(23 \times 3)$ & 69 \\
\hline
\end{tabular}

Sumber: www.idx.co.id Diolah (2020)

Selanjutnya pada Tabel 2 dijelaskan tentang hasil uji statistik deskriptif dari data penelitian ini. Perusahaan yang rata-rata melakukan tax saving sebesar 25,72 persen dengan stuktur modal yang berorientasi pada hutang rata-rata sebesar 66,57 persen. Pertumbuhan penjualan rata-rata mencapai 5,82 persen dengan nilai penyusutan rata-rata sebesar 32,0889 milliar rupiah dan 73,8 persen anggota komite audit memiliki keahlian keuangan.

Tabel 2. Hasil Statistik Deskriptif

\begin{tabular}{cccccc}
\hline Variabel & $\mathrm{n}$ & $\begin{array}{c}\text { Nilai } \\
\text { Terendah }\end{array}$ & $\begin{array}{c}\text { Nilai } \\
\text { Tertinggi }\end{array}$ & $\begin{array}{c}\text { Nilai Rata- } \\
\text { Rata }\end{array}$ & $\begin{array}{c}\text { Simpangan } \\
\text { Baku }\end{array}$ \\
\hline Tax Saving & 69 & 0,189 & 0,334 & 0,2572 & 0,0287 \\
Struktur Modal & 69 & 0,091 & 2,909 & 0,6657 & 0,5489 \\
Sales Growth & 69 & $-0,999$ & 0,352 & 0,0582 & 0,1575 \\
Penyusutan & 69 & 20,962 & 26,601 & 32,0889 & 57,1084 \\
Keahlian Keuangan Komite Audit & 69 & 0,000 & 1,000 & 0,7380 & 0,2870 \\
\hline
\end{tabular}

Sumber: Data Diolah (2020)

Berdasarkan Tabel 3 yang menunjukkan hasil uji asumsi klasik, dapat diketahui bahwa data penelitian terdistribusi normal karena nilai signifikasi uji KolmogorovSmirnov sebesar 0,189 lebih besar dari 0,05. Hasil uji multikolinearitas menunjukkan tolerance value untuk semua amatan diatas 0,10 dan nilai VIF tidak melebihi 10, sehingga tidak terjadi masalah multikolinearitas antar amatan penelitian. Sesuai dengan hasil Durbin Watson test sebesar 2,226 berada diantara $\mathrm{du}<\mathrm{DW}<4$-du atau 1,73425 $<\mathbf{2 , 2 2 6}<2,26575$, sehingga tidak terdapat masalah autokorelasi. Hasil uji heteroskedastisitas dengan uji Glejser juga menunjukkan nilai signifikansi semua variabel amatan lebih besar dari 0,05 setelah diregresikan dengan nilai absolut dari residual amatan. 
Tabel 3. Hasil Uji Asumsi Klasik

\begin{tabular}{cccc}
\hline Keterangan & $\begin{array}{c}\text { Tolerance } \\
\text { Value }\end{array}$ & VIF & $\begin{array}{c}\text { Hasil Uji } \\
\text { Hetroskedastisitas }\end{array}$ \\
\hline Struktur Modal & 0,989 & 1,011 & 0,620 \\
Sales Growth & 0,987 & 1,013 & 0,529 \\
Penyusutan & 0,975 & 1,026 & 0,105 \\
Keahlian Keuangan Komite Audit & 0,971 & 1,030 & 0,789 \\
Hasil Uji Normalitas & 0,189 & & \\
Durbin Watson Test & 2,226 & & \\
\hline
\end{tabular}

Sumber: Data Diolah (2020)

Pengujian data penelitian menggunakan tingkat signifikansi 10 persen dan disajikan pada Tabel 4 yang menunjukkan persamaan regresi dari penelitian ini adalah:

$\mathrm{TS}=0,240+0,001 \mathrm{SM}+0,034 \mathrm{SG}+0,00000000000000208 \mathrm{PYST}+0,011 \mathrm{KK}+\mathrm{e}$

Koefisien regresi masing-masing amatan menunjukkan nilai positif, sehingga peningkatan struktur modal, sales growth, penyusutan maupun keahlian keuangan komite audit akan meningkatkan penghematan pajak yang dilakukan oleh perusahaan. Uji $\mathrm{F}$ menunjukkan $\mathrm{F}_{\text {hitung }}$ sebesar 5,184 dengan tingkat signifikan sebesar 0,001, dikarenakan nilai signifikan lebih kecil dari 0,1 maka dapat di simpulkan bahwa model regresi dalam penelian ini sudah tepat.

Koefisien determinasi (Adjusted $R^{2}$ ) menunjukkan nilai sebesar 0,198 sehingga dapat diartikan bahwa amatan penelitian yaitu struktur modal, sales growth, penyusutan, dan keahlian keuangan komite audit dapat menjelaskan variabel dependen yaitu tax saving sebesar 19,8 \% dan sisanya dijelaskan oleh amatan lain di luar persamaan penelitian.

\section{Tabel 4. Hasil Pengujian Data Penelitian}

\begin{tabular}{ccccc}
\hline Variabel & $\mathrm{b}$ & $\mathrm{t}-$ & Signifikansi & Keterangan \\
\hline Struktur Modal & 0,001 & 0,153 & 0,879 & H1 ditolak \\
Sales Growth & 0,034 & 1,684 & 0,097 & H2 diterima \\
Penyusutan & 0,00000000000000208 & 3,767 & 0,000 & H2 diterima \\
Keahlian Keuangan & 0,011 & 1,033 & 0,305 & H4 ditolak \\
Komite Audit & & & & \\
Konstanta & 0,240 & & & \\
Adjusted R & 0,198 & 5,184 & 0,001 & \\
F-value & & &
\end{tabular}

Sumber: Data Diolah (2020)

Hasil pengujian hipotesis pertama pada Tabel 4 menunjukkan nilai signifikansi sebesar 0,879 yang lebih besar dari 0,1, sehingga $\mathrm{H} 1$ ditolak artinya struktur modal tidak berpengaruh terhadap tax saving. Peningkatan struktur modal yang berasal dari hutang menunjukkan peningkatan penghematan pajak, akan tetapi peningkatan hutang tersebut belum menunjukkan jumlah penghematan pajak yang signifikan yang dilakukan oleh perusahaan. Hasil penelitian ini mengkonfirmasi pernyataan Kieso et al. (2014), jika peningkatan jumlah hutang dapat menurunkan jumlah pajak yang 
harus dibayarkan, dengan cara melakukan hutang jangka panjang dibandingkan yang harus segera dilunasi dalam jangka pendek.

Berdasarkan pengujian data pada Tabel 4 menunjukkan hasil nilai signifikansi sebesar 0,097 dan lebih kecil dari 0,1 atau 10 persen. Oleh karena itu, H2 diterima artinya sales growth berpengaruh terhadap tax saving. Penelitian ini menunjukkan bahwa peningkatan penjualan tahun ini dibandingkan tahun sebelumnya membuat perusahaan harus mengatur pembayaran pajak dengan melakukan tax saving dari kapasitas operasinya. Hal tersebut dikarenakan pertumbuhan penjualan yang meningkat memungkinkan perusahaan mampu meningkatkan kapasitas operasi perusahaan yang justru akan menjadi beban yang menunjang penghematan pajak dengan tetap menjaga perolehan laba perusahaan. Hasil penelitian ini juga mengkonfirmasi temuan Permata et al. (2018).

Hasil pengujian hipotesis ketiga pada Tabel 4 menunjukkan nilai signifikansi sebesar 0,000 yang lebih kecil dari 0,1 atau 10 persen, sehingga H3 diterima artinya penyusutan berpengaruh terhadap tax saving. Besaran jumlah penyusutan aset tetap akan mempengaruhi jumlah laba yang diperoleh perusahaan dan otomatis menentukan jumlah pajak yang dibayar perusahaan. Jumlah penyusutan yang semakin besar tentunya akan menunjang tax saving yang dilakukan oleh perusahaan. Hasil penelitian ini mengkonfirmasi penelitian Pernanda dan Arniati (2013) serta Ritonga (2017), tentunya dengan mempertimbangkan metode penyusutan yang digunakan serta kemungkinan dilakukan penilaian kembali atau revaluasi aset tetap yang dimiliki perusahaan.

Berdasarkan pengujian data pada Tabel 4 menunjukkan hasil nilai signifikansi sebesar 0,305 dan lebih besar dari 0,1. Oleh karena itu, H4 ditolak artinya keahlian keuangan komite audit tidak berpengaruh terhadap tax saving. Penelitian ini menunjukkan bahwa peningkatan keahlian keuangan anggota komite audit independen perusahaan memang mampu membuat perusahaan melakukan penghematan pajak, tetapi jumlah penghematan pajak yang dilakukan belum terlalu signifikan besarannya. Keahlian keuangan anggota komite audit terutama di bidang akuntansi atau keuangan dapat mengontrol manajemen untuk berperilaku sesuai kepentingan para pemangku kepentingan dan tetap mematuhi peraturan perpajakan (Puspita dan Harto, 2014).

\section{Simpulan}

Hasil penelitian ini menunjukkan bahwa sales growth dan penyusutan berpengaruh terhadap tax saving, sedangkan struktur modal dan keahlian keuangan komite audit tidak berpengaruh terhadap tax saving. Berdasarkan penelitian ini upaya untuk menghemat pajak pajak perusahaan dapat dilakukan dengan memperhatikan pertumbuhan penjualan tahun sekarang dengan tahun sebelumnya dan besarnya penyusutan untuk pengambilan keputusan manajer dalam melakukan penghematan pajak. 
Penelitian ini pada dasarnya telah dilakukan pada beberapa amatan, akan tetapi hanya empat amatan yang memenuhi pengujian prasyarat pemodelan dengan regresi. Oleh karena itu penelitian selanjutnya dapat dilakukan dengan menggunakan model regresi dengan aplikasi yang berbeda agar semakin banyak faktor determinan yang dapat diamati. Penelitian ini dilakukan dalam periode penelitian jangka pendek, sehingga masih memungkinkan untuk dilakukan pada periode menengah atau jangka panjang untuk memastikan konsistensi penghematan pajak atau tax saving yang dilakukan oleh perusahaan terbuka yang terdaftar di bursa efek. Penelitian lanjutan juga dapat dilakukan untuk klasifikasi industri yang lain dan membedakan antara yang memiliki tingkat perputaran modal kerja lebih lambat dan lebih cepat dalam melakukan aktivitasnya, agar memberikan gambaran tentang tax saving dikaitkan dengan perolehan laba perusahaan.

\section{Daftar Pustaka}

Agoes, S., dan E. Trisnawati. 2013. Akuntansi Perpajakan, Edisi 3. Jakarta: Salemba Empat.

Aprianto, M., dan S. Dwimulyani. 2019. Pengaruh Sales Growth dan Leverage Terhadap Tax Avoidance dengan Kepemimpinan Institusional sebagai Variabel Moderasi. Prosiding Seminar Nasional Pakar ke 2 Tahun 2019, Buku 2: Sosial Humaniora. Fakultas Ekonomi dan Bisnis Universitas Trisakti: 21401-21410.

Brigham, E. F., dan J. F. Houston. 2011. Dasar-Dasar Manajemen Keuangan (Terjemahan), Edisi 10. Jakarta: Salemba Empat.

Budiman, J., dan Setiyono. 2012. Pengaruh Karakter Eksekutif Terhadap Penghindaran Pajak (Tax Avoidance). Proceeding Simposium Nasional Akuntansi XV. Universitas Lambung Mangkurat, Banjarmasin.

Darmadi, I. N. H., dan Zulaikha. 2013. Analisis Faktor yang Mempengaruhi Manajemen Pajak dengan Indikator Tarif Pajak Efektif. Proceeding Simposium Nasional Akuntansi XVII. Universitas Mataram, Mataram.

Direktorat Jenderal Pajak Republik Indonesia. 2020. Betapa Krusialnya Pajak dalam Portal Kehidupan Berbangsa dan Bernegara. [Artikel Online] Available at: https://www.pajak.go.id/id/artikel

Djuharni, D., dan Y. Y. E. Bezaliel. 2019. Penentuan Metode Penilaian Persediaan dan Metode Penyusutan Aset Tetap untuk Tax Planning. Journal of Islamic Accounting and Tax. 2(2): 140-148.

Fani dan Wibowo, S. 2017. Pengaruh Sales Growth, Leverage, Ukuran Perusahaan, dan Komite Audit Terhadap Praktik Penghindaran Pajak Pada Perusahaan Manufaktur yang Terdaftar di Bursa Efek Indonesia Tahun 2011-2015. Jurnal Ilmiah Akuntansi dan Teknologi. 9(2): 1-6.

Ghozali, I. 2011. Aplikasi Analisis Multivariate Dengan Program SPSS, Edisi V. Semarang: Badan Penerbit Universitas Diponegoro.

Ikatan Akuntan Indonesia (IAI). 2018. Standar Akuntansi Keuangan. Jakarta: Salemba Empat.

Kieso, D. E., J. J. Weygant, dan T. D. Warfield. 2014. Intermediate Accounting IFRS Edition. United States of America: Wiley Publishing. 
Mahanani, A., K. H. Titisari, dan S. Nurlaela. 2017. Pengaruh Karakteristik Perusahaan, Sales Growth dan CSR Terhadap Tax Avoidance. Prosiding Seminar Nasional IENACO-2017: 732-742.

Peraturan Otoritas Jasa Keuangan. 2015. Nomor 55/POJK.04 tentang Pembentukan dan Pedoman Pelaksanaan Kerja Komite Audit.

Permata, A. D., S. Nurlela, dan E. Masitoh W. 2018. Pengaruh Size, Age, Profitability, Leverage dan Sales Growth Terhadap Tax Avoidance. Jurnal Akuntansi dan Pajak. 19(1): 10-20.

Pernanda, D., dan Arniati. 2013. Perencanaan Pajak dalam Rangka Penghematan Pembayaran Pajak Terutang (Studi Kasus pada PT. GL HI TECH INDONESIA). Jurnal Akuntansi, Ekonomi dan Bisnis Politeknik Batam. 1(1): 68-82.

Puspita, S. L., dan P. Harto. 2014. Pengaruh Tata Kelola Perusahaan Terhadap Penghindaran Pajak. Diponegoro Journal of Accounting. 1(1): 1-13.

Ritonga, P. 2017. Analisis Perencanaan Pajak Melalui Metode Penyusutan dan Revaluasi Aset Tetap untuk Meminimalkan Beban Pajak pada PT. TASPEN (Persero) Cabang Utama Medan. Jurnal Riset Akuntansi dan Bisnis. 17(1): 1-14.

Robinson, J. R., Y. Xue, Yanfeng, dan M. H. Zhang. 2012. Tax Planning and Financial Expertise in the Audit Committee. SSRN Working Paper [Online]. Available at SSRN: http://dx.doi.org/10.2139/ssrn.2146003

Ruchjana, E. T. 2008. Analisis Penerapan Metode Gross-Up dalam Perhitungan PPh 21 Sebagai Salah Satu Upaya Perencanaan Pajak (Studi Kasus pada PT BPR XYZ Tahun 2005). Jurnal Manajemen, 6(2):261-270.

Sahilatua, P. F., dan N. Noviari. 2013. Penerapan Perencanaan Pajak Penghasilan Pasal 21 Sebagai Strategi Penghematan Pembayaran Pajak. E-Jurnal Akuntansi Universitas Udayana. 5(1): 231-250.

Sudarmika, G.Y., dan M. S. N. Sudirman. 2015. Pengaruh Profitabilitas, Pertumbuhan Aktiva, Struktur Aktiva, dan Pajak Terhadap Struktur Modal. E- Jurnal Manajemen Unud. 4(9): 2857-2885.

Undang-Undang Nomor 36. 2008. Pajak Penghasilan.

Wahyuni, I. A. T., dan N. P. S. Suryantini. 2014. Pengaruh Ukuran Perusahaan, Profitabilitas dan Penghematan Pajak Terhadap Struktur Modal. E-Jurnal Manajemen. 3(5): 14571470 . 
